\title{
Potential anticancer activities of chloroform subfraction from Peronema leaf on colon cancer HT-29 cells in vitro
}

\author{
Arsyik Ibrahim $^{1,2 *}$ (D), Siswandono Siswandono ${ }^{3}$, Bambang Prajogo Eko Wardojo ${ }^{3}$ \\ ${ }^{1}$ Doctoral Program, Faculty of Pharmacy, University of Airlangga, Surabaya, Indonesia. \\ ${ }^{2}$ Department of Pharmaceutical Sciences, Faculty of Pharmacy, University of Mulawarman, Samarinda, Indonesia. \\ ${ }^{3}$ Department of Pharmaceutical Sciences, Faculty of Pharmacy, University of Airlangga, Surabaya, Indonesia.
}

\begin{tabular}{l}
\hline ARTICLE INFO \\
\hline Received on: 20/07/2021 \\
Accepted on: 01/09/2021 \\
Available Online: 05/12/2021 \\
\\
\hline Key words: \\
Cytotoxicity, HT-29 cells, \\
In vitro cell lines assay, \\
Peronema canescens Jack, \\
Secondary metabolites.
\end{tabular}

\begin{abstract}
A study on the cytotoxic activity of Sungkai (Peronema canescens Jack) used in vitro cell lines has not been reported. Peronema canescens leaves contain many secondary metabolites with potential cytotoxic activity. In vitro cell lines assay can be used to determine natural products' anticancer activity. This study aimed to identify secondary metabolites of $P$. canescens leaf chloroform fraction and subfraction and to determine the effect of cytotoxicity $\left(\mathrm{IC}_{50}\right)$ on HT-29 colon cancer cells. In this study, the cytotoxicity activities on HT-29 cells were evaluated by 3-(4,5-dimethylthiazol2-yl)-2,5-diphenyltetrazolium bromide assay using concentration ranges from 1.563 to $200.00 \mu \mathrm{g} / \mathrm{ml}$. The detected secondary metabolites in the chloroform were alkaloids, terpenoids, steroids, flavonoids, and phenolics. The value of cytotoxic activity $\left(\mathrm{IC}_{50}\right)$ against HT-29 colon cancer cells ranged from 14.807 to $34.448 \mu \mathrm{g} / \mathrm{ml}$. The tests carried out showed that chloroform subfraction 3 showed potential cytotoxic activity in human HT-29 cancer cells with an $\mathrm{IC}_{50}$ value of $14.807 \mu \mathrm{g} / \mathrm{ml}$ and provided promising hope for further cytotoxicity studies.
\end{abstract}

\section{INTRODUCTION}

Cancer is a disease caused by decreased apoptosis activity and dysregulation of abnormal cell proliferation that attacks and disturbs surrounding tissue, and the spread is not controlled, resulting in death (Mas'ula and Kusuma, 2015). Mutations cause almost all cancer cases by genetic damage and thus the loss of cellular regulation. The first mutation caused by cell division results in a homogeneous genetic clone; then, further mutations occur, which cause an increased potential cell growth (American Cancer Society, 2017).

Colorectal cancer is caused by abnormal cells in the colon or rectum and often begins as a growth called polyps in the colon or rectum. Most colorectal cancers are adenocarcinoma. Natural products have various effects on human health, such as suspected chemopreventive properties (anticarcinogenic and antimutagenic),

\footnotetext{
*Corresponding Author

Arsyik Ibrahim, Department of Pharmaceutical Sciences, Faculty of

Pharmacy, University of Mulawarman, Samarinda, Indonesia.

E-mail: achie.ibrahim@gmail.com.
}

and interfere with tumor promotion and development (Macdonald et al., 2005; National Cancer Institute, 2020). The secondary metabolites (such as alkaloids, terpenoids, flavonoids, phenolics, and organic acids) found in various plants have been shown to inhibit cancer cells' growth (Fadilah et al., 2017; Gautam, 2015). In most living organisms formed among other alkaloids, terpenoids and flavonoids have potential anticancer activities (Saifudin, 2014; Yang and Dou, 2010).

The genus Peronema in the plant taxonomic system has only one known species, namely Peronema canescens Jack (Turner, 1995). This species, from the Verbenaceae family, is a tree that grows in tropical areas in Indonesia (regional names jati sabrang, ki sabrang, sungkai and sekai), Thailand, and Malaysia (Panjaitan and Nuraeni, 2014; Tropical Plants, 2019). In Indonesia, this species is well known in Sumatera, Kalimantan, Java, and Sulawesi (Rosdiana, 2014). Empirically, the genus Peronema has been used in traditional medicine. Researchers have reported several plant activities such as antioxidants (Rosdiana, 2014; Widodo et al., 2019), antipyretics, and enhanced immunity (Yani and Putranto, 2014). Phytochemicals are nonnutritive plant secondary metabolites that exhibit either protective or disease 
preventive properties (Vidyacharani and Arunprasath, 2020). Plants possess various phytochemicals with several bioactivities such as anti-inflammatory, antioxidant, and anticancer (Samatha et al., 2012).

Phytochemical investigations on the family Verbenaceae, genus Peronema, led to the isolation of biologically active compounds including $\beta$-sitosterol, phytol, $\beta$-amyrin, and peronemins A1, A3, B2, B2, B3, C1, and D1 (Kitagawa et al., 1994). Lantaden A, lantaden B, lanthanolic acid, lanthanic acid, and lantonin alkaloids are the ingredients (Harmida et al., 2011). Secondary metabolites of $P$. canescens leaf include alkaloids, terpenoids, steroids, flavonoids, phenolics, and saponins (Ahmad and Ibrahim, 2015; Rosdiana, 2014; Widodo et al., 2019), which have a cytotoxic potential mainly as anticancer (Fadilah, et al., 2017; Yang and Dou, 2010).

Empirically, the leaf from the genus Peronema commonly known as "Sungkai" has been used in traditional medicine by the Indonesian people, especially the Dayak tribe in East Kalimantan, for the treatment of cold and fever, ringworms, and toothache (Ibrahim and Kuncoro, 2012). However, scientific data are minimal. The methanol extract and hexane and ethyl acetate fraction of this plant's leaves have been tested for bioactivity using animal models of the Brine Shrimp Lethality Test (BSLT) method. The test results show that methanol, hexane, and ethyl acetate extracts are toxic to animal model marine shrimp larvae (Ahmad and Ibrahim, 2015). Therefore, we evaluated the cytotoxic effect of the chloroform fraction of $P$. canescens leaf. This study aims to identify secondary metabolites and prevent cytotoxicity with colon cancer cells (HT-29) as targets so that they can be developed as alternative drugs in cancer treatment.

\section{MATERIALS AND METHODS}

\section{Materials}

The sample of $P$. canescens leaf was obtained from Tanah Merah Subdistrict, Samarinda, East Kalimantan, in May 2019. The fresh Simplicia was determined at the Dendrology and Forest Ecology Laboratory of the Faculty of Forestry, Mulawarman University, Samarinda. The voucher specimen (33/H17.4.1.08/LL/VI/.2011) was stored at Pharmaceuticals Research and Development Laboratory of FARMAKA TROPIS, Faculty of Pharmacy Universitas Mulawarman, Samarinda East Kalimantan, Indonesia. In this study, the chemical materials used included methanol p.a, hexane p.a, chloroform p.a, (Merck, Indonesia), 5-fluorouracil (Adrucyl ${ }^{\circledR}$, Indonesia), and silica gel G 60 (Merck ${ }^{\circledR}$, Darmstadt, USA). Chemicals and all other standard reagents were purchased from Sigma Chemical Company ( $\mathrm{St}$ Louis, MO). Dulbecco's Modified Eagle Medium (Roswell Park Memorial Institute; Gibco BRL, Life Technologies, USA), trypsinEDTA (Ethylenediaminetetraacetic acid) solution, and fetal bovine serum (Sigma Chemical Company, St Louis, MO) were used. $1 \%$ penicillin and streptomycin were from Meiji, Indonesia. Phosphate buffer saline (PBS) was from Biomatic, Canada, USA. Dimethyl sulfoxide (DMSO) was from Biomatic, Canada, USA. 3-(4,5-dimethylthiazol-2-yl)-2,5-diphenyltetrazolium bromide (MTT), reagents stopper sodium dodecyl sulfate $10 \%$ (SDS, Merck ${ }^{\circledR}$, Darmstadt, Germany), yellow tips, and blue tips (Neptune, USA) were used. Tissue culture flask of $25 \mathrm{~cm}$ was from Biologix Group Limited. Moreover, other tools were used, including laminar airflow (Biobase, Indonesia), $\mathrm{CO}_{2}$ incubator Galaxy ${ }^{\circledR} 170 \mathrm{~S}$ (Eppendorf, Germany), inverted microscopy (CKX53, Olympus, USA), and enzyme-linked immunosorbent assay (ELISA) (Model 550, Bio-Rad, USA).

\section{Extraction process}

The leaves of $P$. canescens were cleaned, dried, and ground into a powder before extraction with methanol using a macerator. The resultant, after filtration and evaporation by rotary under vacuum pressure, was stored for fractionation. A dried sample of $P$. canescens leaves was macerated using $95 \%$ methanol for $1 \times 24$ hours. After the extraction process, the residue and extract solution were separated using the Buchner funnel, and then the extract solution was evaporated to obtain a concentrated extract using a rotary evaporator. The extract was stored at room temperature until ready for use.

\section{Fractionation}

According to a previous study, the fractionation process was conducted using the vacuum column chromatography (VCC) (Vukovic et al., 2018), with some modification. Briefly, the extracted sample (12 g) was dissolved with a hexane solvent and then impregnated with $6 \mathrm{~g}$ of silica gel G 50-100 mesh and then crushed until homogeneous. The dried sample was separated using VCC, with a column size of $13 \mathrm{~cm}$, height of $24 \mathrm{~cm}$, and 1,000 $\mathrm{ml}$ successive polarity gradient eluents: hexane, chloroform, ethyl acetate, and methanol. The obtained fraction was stored using a vial and prepared for the next separation phase. The chloroform fraction was refractionated using the VCC column size with the fractionation process and $100 \mathrm{ml}$ successive polarity gradient ratio eluents: hexane:ethyl acetate and methanol (hexane, 90:10, 80:20, $70: 30,60: 40,50: 50,40: 60,30: 70,20: 80$, and 10:90, methanol). Furthermore, the subfractions that showed a similar pattern on thinlayer chromatography (TLC) (hexane:ethyl acetate $=8: 2$ ) after visualization with a UV lamp at 254 and $365 \mathrm{~nm}$ were combined in 6 subfractions (SF1-SF6). The fractions were evaporated with a rotary evaporator to get concentrated extracts. The extract was stored at room temperature until ready for the test.

\section{Cytotoxicity test MTT method}

Suspension of HT-29 colon cancer cells $(100 \mu \mathrm{l})$ with a density of $2 \times 10^{4}$ cells $/ 100 \mu \mathrm{l}$ was inserted into the 96-well disk and incubated for 24 hours in a $\mathrm{CO}_{2}$ incubator. $100 \mu$ of test solution was added to the well with a series of concentrations: $1.562,3.123,6.25,12.50,25.00,50.00,100.00$, and $200.00 \mu \mathrm{g} /$ $\mathrm{ml}$. The MTT reagent $(0.5 \mathrm{mg} / \mathrm{ml}$ in PBS $)$ was added to each well. The cells were then incubated in a $\mathrm{CO}_{2}$ incubator for 2-4 hours at $37^{\circ} \mathrm{C}$ for 4 hours. The negative control uses $100 \mu \mathrm{l}$ DMSO. The anticancer drug 5-fluorouracil was used as a positive control toward HT-29 cells. Cell condition was examined by inverted microscopy. $100 \mu \mathrm{l}$ sodium dodecyl sulfate $10 \%$ stopper was added to $0.1 \mathrm{~N} \mathrm{HCl}$ if formazan was formed. The microplate was wrapped in aluminum foil and incubated in a dark place at room temperature for 24 hours. The living cells reacted with MTT to form a purple color. The absorbance was determined using an ELISA reader at 90-590 $\mathrm{nm}$ (Halimatushadyah et al., 2018; Xiong et al., 2015; Yao et al., 2017). 
The percentage of inhibition was calculated to get the $\mathrm{IC}_{50}$ value. $\mathrm{IC}_{50}$ is a concentration of $50 \%$ growth inhibition of the cell population to determine its cytotoxic potential. $\mathrm{IC}_{50}$ values were determined by probit analysis [Product Solutions and
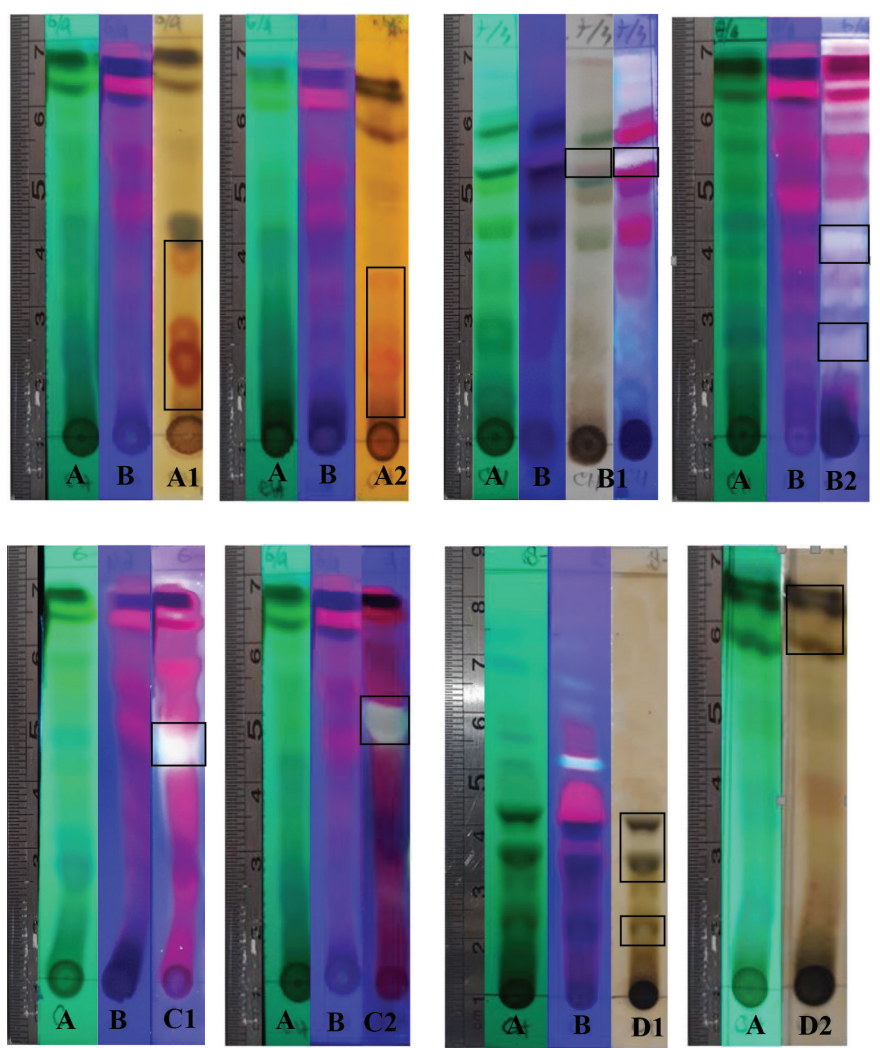

Figure 1. Profile of secondary metabolite chromatograms of chloroform fraction visualization with UV lamp at $254 \mathrm{~nm}(\mathrm{~A})$ and $365 \mathrm{~nm}$ (B) reagent compound detection. Wagner (A1) and Dragendorff (A2). Lieberman-Bouchard and vanillin- $\mathrm{H}_{2} \mathrm{SO}_{4}$ (B1) and phosphoric acid (85\%) (B2). Aluminum (III) chloride (C1) and cytroborate (C2). Iron (III) chloride (D1 and D2).
Service Statistics (Statistical Package for the Social Sciences) 22.0 for Windows].

\section{RESULTS AND DISCUSSION}

\section{Profile of secondary metabolites}

The secondary metabolites test was carried as an initial step to detect compounds contained in natural biological materials. Secondary metabolites of Peronema leaf chloroform fraction and the most potent subfraction 3 (SF3) were identified using specific spray chemical reagents. Dragendorff and Wagner reagents were used for alkaloids compounds detection. Lieberman-Bouchard, vanillin sulfuric acid, and $85 \%$ phosphoric acid were used for terpenoid-sterols compounds. Iron (III) chloride was used for phenolic compounds. The profile of secondary metabolites of chloroform fraction is shown in Figure 1 and Table 1, and SF3 is shown in Figure 2 and Table 2 using TLC plates with specific diagnostic reagents.

The positive reactions to the alkaloid test are shown in Figure 1 and Table 1. The metal ion bismuth complex $\left(\mathrm{Bi}^{3+}\right)$ reaction with the alkaloid compounds produced an orange color for the Dragendorff test (Sutrisno, 1993), while for the Wagner test, the complex reaction between alkaloids and $\mathrm{K}^{+}$ions from potassium tetraiodobismutate produced a brown color (Haryati et al., 2015). The color products on the TLC plates of the two reagents are shown in Figure 1 (A2 and A1) in square marks.

The positive reactions data to the terpenoids, steroid, and sterol tests are shown in Figures 1 and 2 and Table 2. The result showed that red, white, and greenish fluorescent colors were positive reactions for vanillin sulfate, Liebermann-Burchard for terpenoids tests, and opaque white fluorescent at $366 \mathrm{~nm} \mathrm{UV}$ light for steroid compound tests (Halimatushadyah et al., 2018). The difference in luminescence between terpenoid and steroids compounds was due to the sulfate ionization $\left(\mathrm{SO}_{2}^{-}\right)$reaction in the group on the $\mathrm{C}-4$ atom, where the steroid compound contains a hydroxyl group $\left(\mathrm{OH}^{-}\right)$(Haryati et al., 2015). The color products of the three reagents on the TLC plate are shown in Figures 1 (B1 and

Table 1. Secondary metabolites' chloroform fraction.

\begin{tabular}{|c|c|c|c|c|c|}
\hline Compound group & Reagents & Reaction & Chromo & Rf value (cm) & Eluent \\
\hline \multirow[t]{2}{*}{ Alkaloids } & Wagner & + & Brown & $\begin{array}{c}0.62 ; 0.47 ; 0.45 \\
0.42\end{array}$ & $\begin{array}{c}\text { Hexane:ethyl } \\
\text { acetate }(6: 4)\end{array}$ \\
\hline & Dragendorff & + & Orange & $\begin{array}{c}0.62 ; 0.47 ; 0.45 \\
0.42\end{array}$ & \\
\hline \multirow[t]{2}{*}{ Terpenoids } & $\begin{array}{c}\text { Lieberman- } \\
\text { Bouchard }\end{array}$ & + & White fluorescent & 0.88 & $\begin{array}{c}\text { Hexane:ethyl } \\
\text { acetate }(7: 3)\end{array}$ \\
\hline & Vanillin- $\mathrm{H}_{2} \mathrm{SO}_{4}$ & + & Red & 0.88 & \\
\hline Steroids & $85 \% \mathrm{H}_{3} \mathrm{PO}_{4}$ & + & $\begin{array}{l}\text { Opaque white } \\
\text { fluorescent }\end{array}$ & $0.66 ; 0.44$ & $\begin{array}{c}\text { Hexane:ethyl } \\
\text { acetate }(6: 4)\end{array}$ \\
\hline \multirow[t]{2}{*}{ Flavonoids } & $\mathrm{AlCl}_{3}$ & + & $\begin{array}{c}\text { Yellowish glow } \\
\text { fluorescent }\end{array}$ & 0.65 & $\begin{array}{c}\text { Hexane:ethyl } \\
\text { acetate }(6: 4)\end{array}$ \\
\hline & $\mathrm{H}_{3} \mathrm{BO}_{3}$ & + & $\begin{array}{l}\text { Yellowish green } \\
\text { fluorescent }\end{array}$ & 0.65 & \\
\hline \multirow[t]{2}{*}{ Phenolic } & $\mathrm{FeCl}_{3}$ & + & Black & $0.52 ; 0.43 ; 0.20$ & $\begin{array}{c}\text { Hexane:ethyl } \\
\text { acetate }(8: 2)\end{array}$ \\
\hline & & + & Black & $0.92 ; 0.81$ & $\begin{array}{c}\text { Hexane:ethyl } \\
\text { acetate }(4: 6)\end{array}$ \\
\hline
\end{tabular}


B2) and 2 (B-D) in square marks. The positive reactions showed black spots using diagnostic reagent iron (III) chloride $\left(\mathrm{FeCl}_{3}\right)$ for phenolic compounds. The result is shown in Figures 1 (D1 and D2) and $2(\mathrm{E})$ in square marks. The mechanism of the phenolic reaction forms a black complex, where the $-\mathrm{OH}$ group in the aromatic ring reacts with $\mathrm{FeCl}_{3}$. The color complex formed was considered iron (III) hexafluoride, which undergoes a bathochromic shift toward a larger wavelength (Saleh and Marliana, 2011).

\section{Effect of MTT assay on human colon cancer cell lines}

In vitro cytotoxicity testing was carried out as an initial screening for potential anticancer compounds. This test
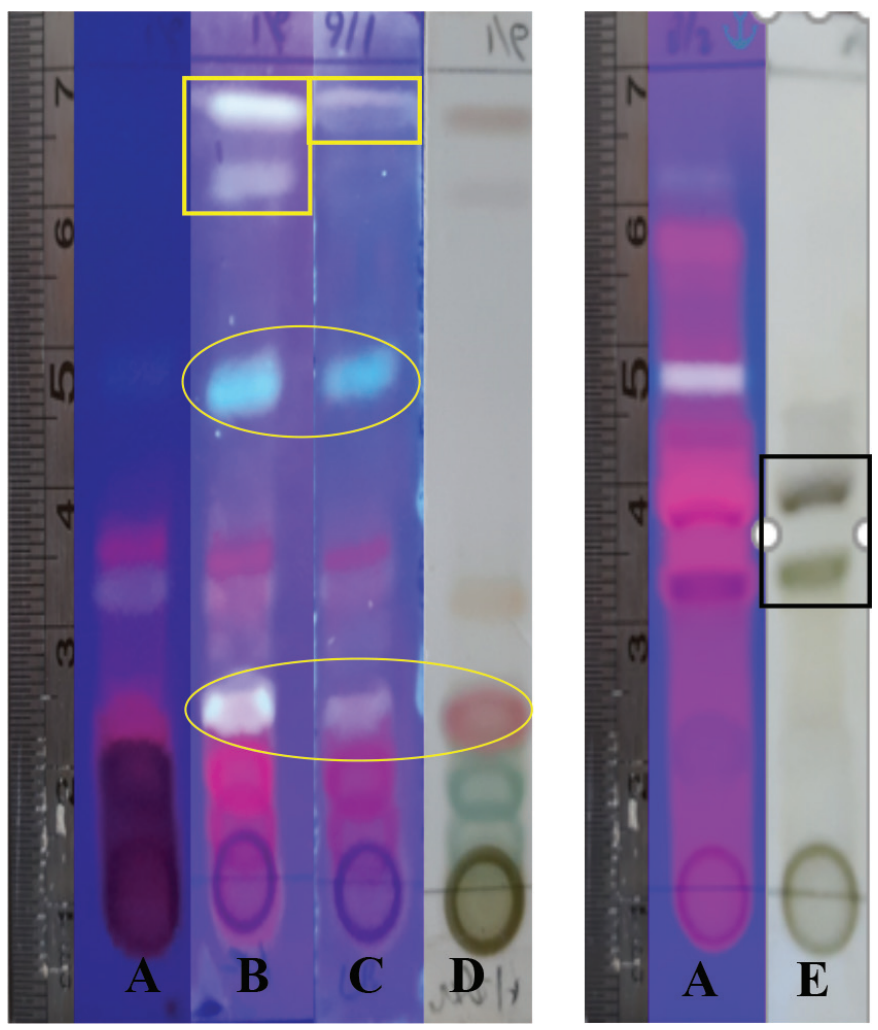

Figure 2. Profile of secondary metabolite chromatograms of chloroform SF3 with various reactions: UV lamp at $365 \mathrm{~nm}$ (A), 85\% phosphoric acid (B), Lieberman-Bouchard (C), and vanillin- $\mathrm{H}_{2} \mathrm{SO}_{4}$ (D) were terpenoid, steroid, and sterol reagents. Iron (III) chloride (E) was phenolic reagents. uses cell lines with several advantages, such as less material and less time consumption (Fadilah et al., 2017). The MTT assay was used to maintain cell viability and proliferation of macrophage-mediated cytotoxicity. The results of cell viability changes are shown in Figure 3. The graphic shows that \%viability decreases with increasing extract concentration to $200 \mu \mathrm{g} / \mathrm{ml}$ in both cell lines. Morphological and cytotoxic effects of cells are shown in Figure 4. All cells were exposed to various concentrations: $1.562,3.123,6.25,12.50,25.00$, $50.00,100.00$, and $200.00 \mu \mathrm{g} / \mathrm{ml}$. Morphologically, normal (control) cells look transparent oval and attached to the tissue culture dish. After the extract treatment, some cells appear compact (x), expanded (y), and shrunken (z); this is thought of as possible cell condensation, nucleus shrinkage, and cytosolic granulation; cells dying during exposure; cell membranes hardening; and blebbing.

An $\mathrm{IC}_{50}$ was determined based on concentrations that induce $50 \%$ inhibition of treated cell growth than untreated cells in triplicate after 24 hours of the treatment. The expected limit of cytotoxic activity was the compound's deposition of fewer than $20 \mu \mathrm{g} / \mathrm{ml}$ after 24 hours of exposure (Geran et al., 1972). Percent inhibition has a good relationship with chloroform fraction, subfractions concentration of Peronema leaves, and control positive (5-fluorouracil), as shown in Figure 5. Anticancer activity of chloroform fractions and subfractions $\left(\mathrm{IC}_{50} \mu \mathrm{g} / \mathrm{ml}\right)$ in HT-29 cells can be seen in Figure 6.

The results obtained in this study found that the chloroform extract fraction and its subfraction showed cytotoxic activity, and the highest anticancer activity was SF3 $\left(\mathrm{IC}_{50}=14.807 \mu \mathrm{g} / \mathrm{ml}\right)$. However, they were categorized as cytotoxic agents (each $\mathrm{IC}_{50}$ value less than $20 \mu \mathrm{g} / \mathrm{ml}$ is considered cytotoxic). The American National Cancer Institute guidelines and Geran et al. (1972) set a concentration limit for the $50 \%$ inhibitory activity $\left(\mathrm{IC}_{50}\right)$ of the compound, which is less than $20 \mu \mathrm{g} / \mathrm{ml}$ after 24 hours exposure (Geran et al., 1972). The results above indicate that the content of secondary metabolites in the chloroform subfractions of Peronema leaves is a potential anticancer agent.

\section{CONCLUSION}

In this work, preliminary data were obtained for further research, particularly cytotoxicity. Moreover, these data were first reported from the genus Peronema, apart from helping

Table 2. Secondary metabolites' chloroform SF3.

\begin{tabular}{|c|c|c|c|c|c|}
\hline $\begin{array}{l}\text { Compound } \\
\text { group }\end{array}$ & Reagents & Reaction & Chromo & Rf value (cm) & Eluent \\
\hline Steroids & $85 \% \mathrm{H}_{3} \mathrm{PO}_{4}$ & + & $\begin{array}{l}\text { Opaque white } \\
\text { and greenish } \\
\text { fluorescent }\end{array}$ & $\begin{array}{c}0.97 ; 0.87 ; 0.62 ; \\
0.25\end{array}$ & $\begin{array}{c}\text { Hexane-ethyl acetate } \\
(9: 1)\end{array}$ \\
\hline \multirow[t]{2}{*}{ Terpenoids } & Lieberman-Bouchard & + & $\begin{array}{l}\text { White and } \\
\text { greenish } \\
\text { fluorescent }\end{array}$ & $0.97 ; 0.620 .25$ & $\begin{array}{c}\text { Hexane-ethyl acetate } \\
(9: 1)\end{array}$ \\
\hline & Vanillin- $\mathrm{H}_{2} \mathrm{SO}_{4}$ & + & Red & 0.25 & \\
\hline Phenolic & Iron (III) chloride & + & Black & $0.66 ; 0.38$ & $\begin{array}{c}\text { Hexane-ethyl acetate } \\
(8: 2)\end{array}$ \\
\hline
\end{tabular}




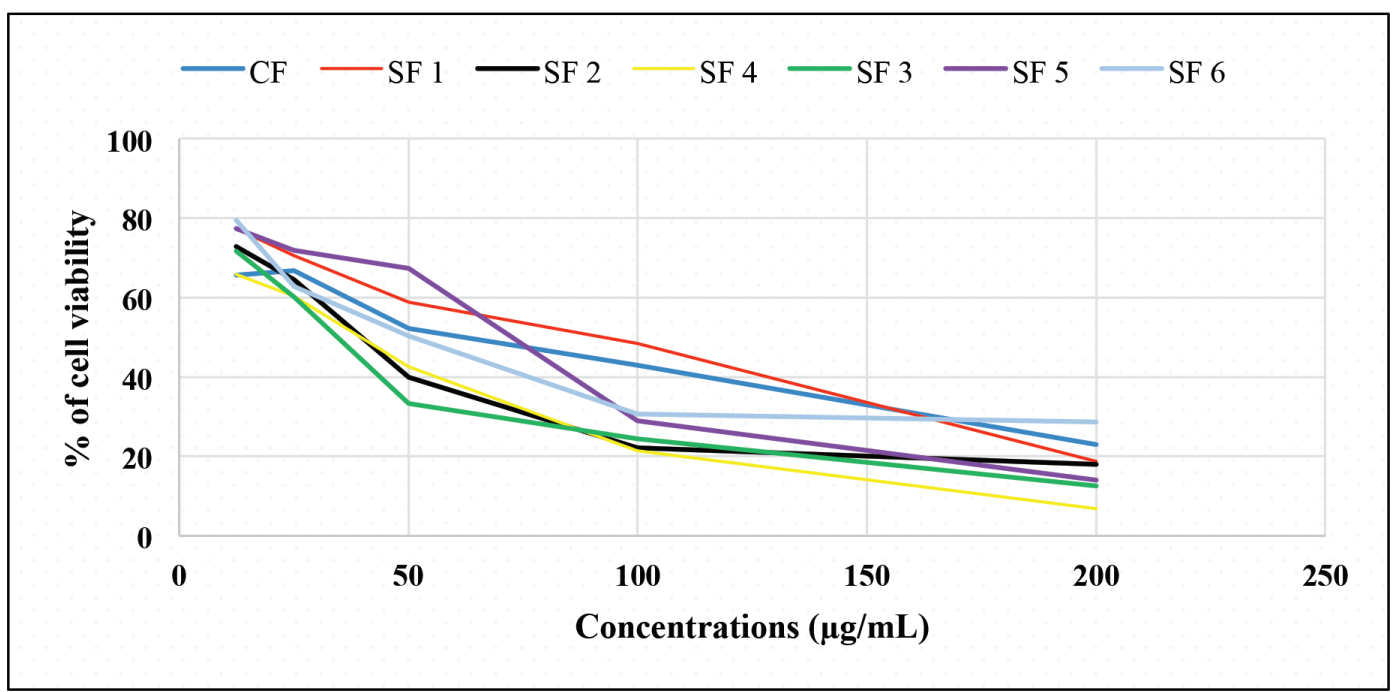

Figure 3. The percentage of cell viability of each fraction and subfraction chloroform test. CF: chloroform fraction, SF1: subfraction 1, SF2: subfraction 2, SF3: subfraction 3, SF4: subfraction 4, SF5: subfraction 5, and SF6: subfraction 6.
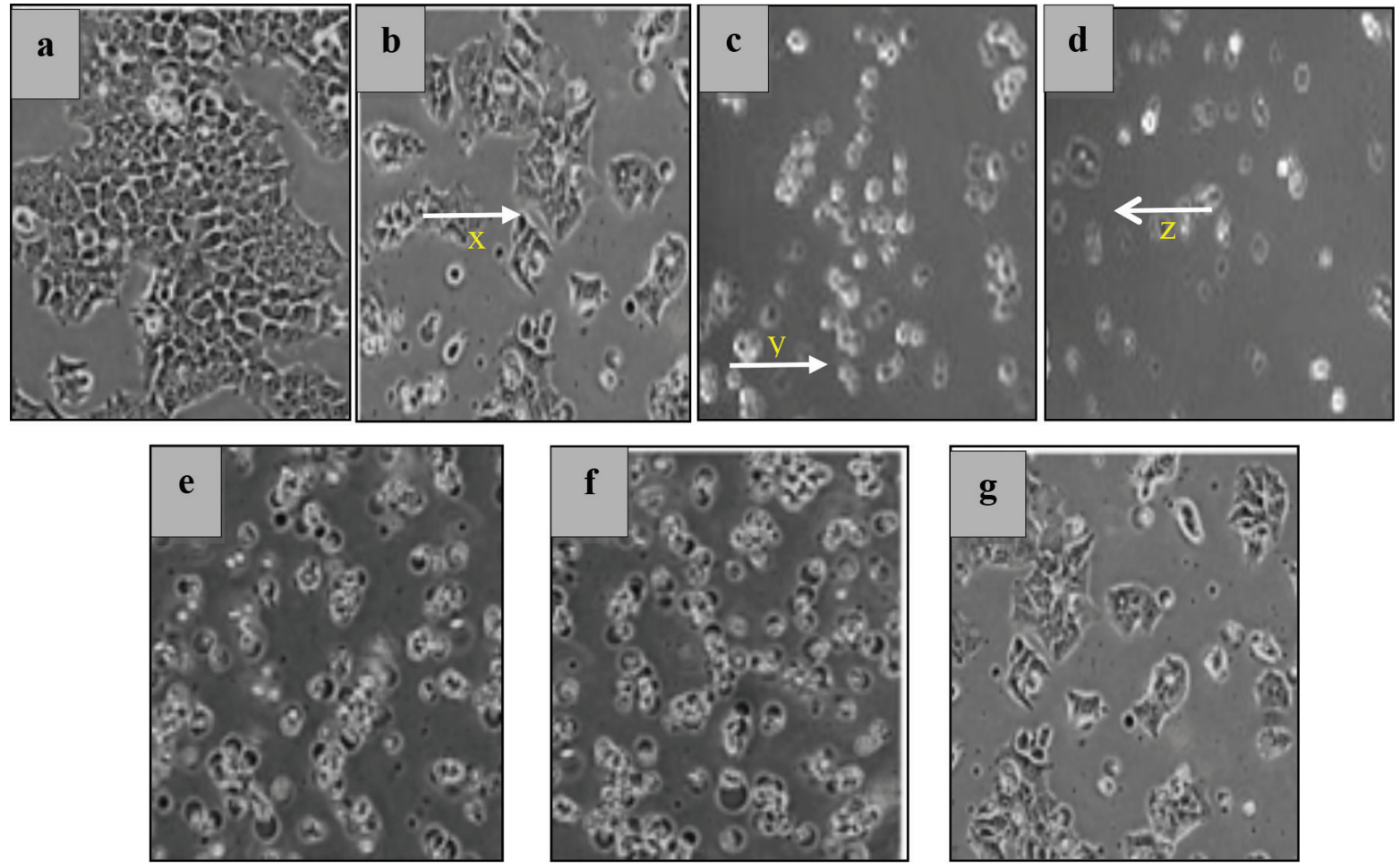

Figure 4. The morphology of HT-29 cells examined under a microscope $(200 \times)$. Inhibitory control (a). Changes after treatment at high concentrations of $200 \mu \mathrm{g} / \mathrm{ml} \mathrm{SF} 1$ (b), SF2 (c), SF3 (d), SF4 (e), SF5 (f), and SF6 (g) of HT-29 colon cancer cells. The cells appear compact $(x)$, expanded (y), and shrunken (z).

detect secondary metabolites, which will later assist in further research, and especially for the search for anticancer compounds from this plant.

\section{ACKNOWLEDGMENTS}

The authors acknowledge the financial support provided by the Faculty of Pharmacy, University of Mulawarman, in 2019 for their research project. They thank the Head of Research and Development Laboratory of FARMAKA TROPIS for the assistance permits, facilities to support this research, and cooperation.

\section{AUTHOR CONTRIBUTIONS}

All authors made substantial contributions to conception and design, acquisition of data, or analysis and interpretation of 

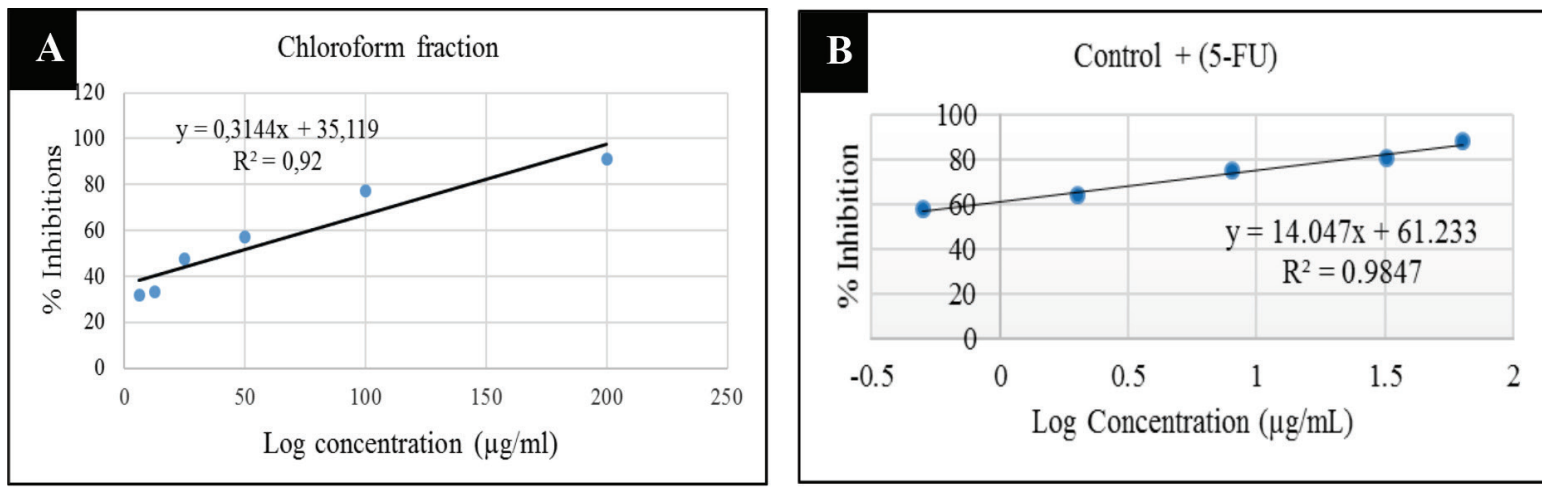
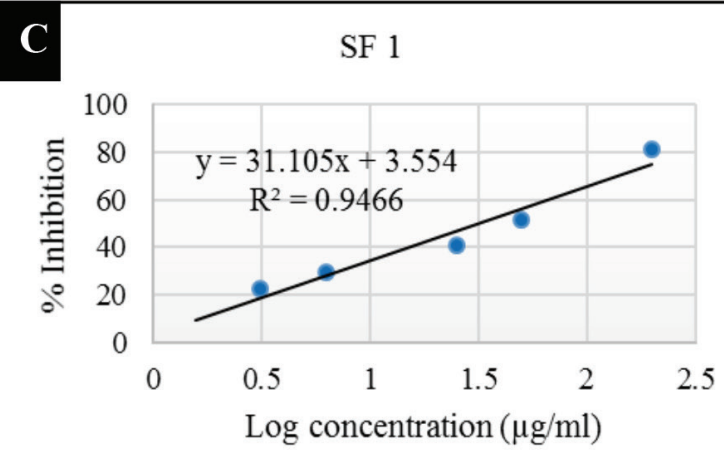

$\mathbf{E}$

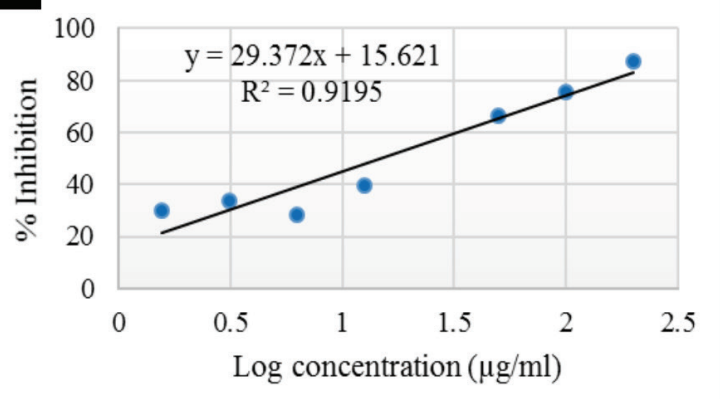

\section{G}

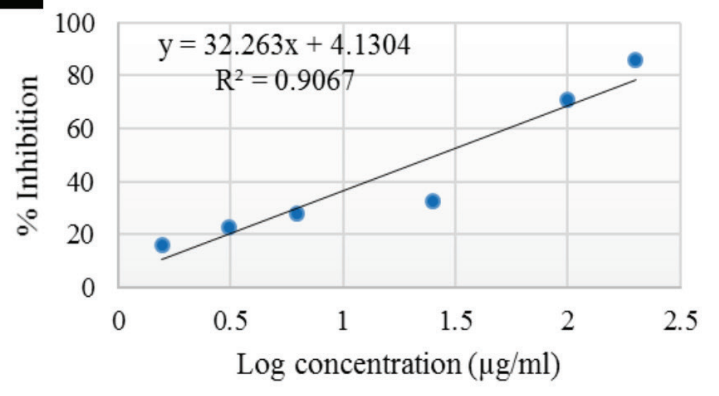

D SF 2

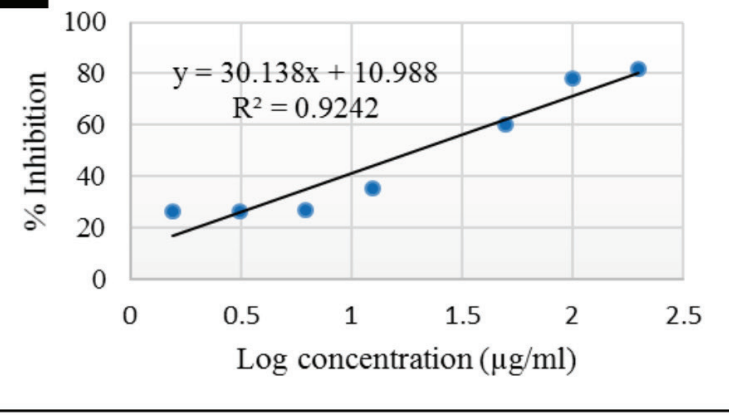

F SF 4

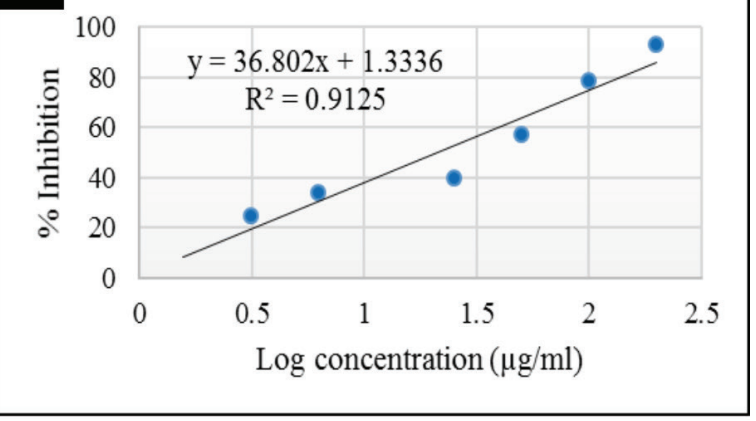

H

SF 6

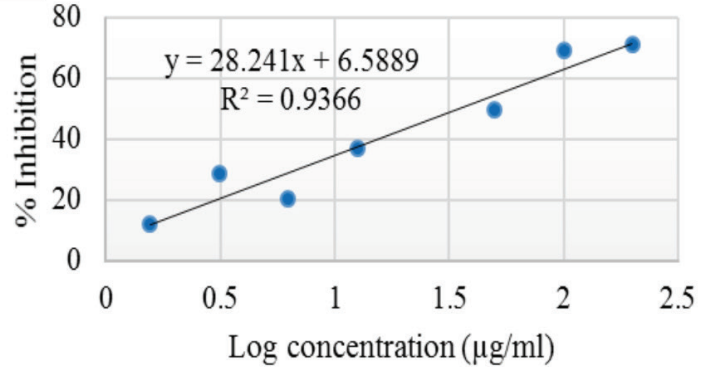

Figure 5. Relationship of chloroform fraction (A), and subfractions concentration of Peronema leaf (C-H), and control positive (5-fluorouracil) (B) with percent of inhibition of HT-29 colon cancer cells. 


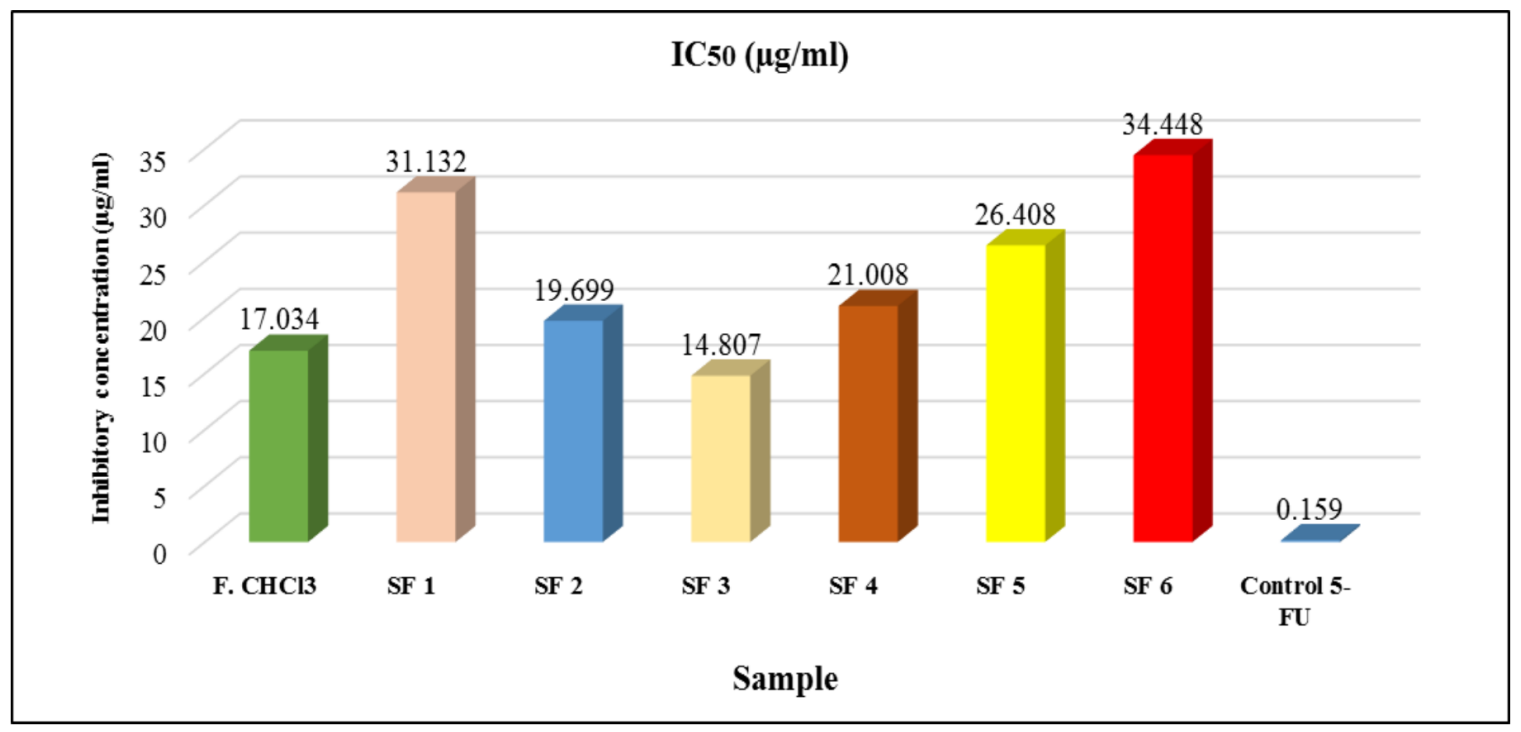

Figure 6. Cytotoxicity $\left(\mathrm{IC}_{50}\right)$ value of chloroform fraction and subfraction of Peronema leaf in HT-29 colon cancer cells.

data; took part in drafting the article or revising it critically for important intellectual content; agreed to submit to the current journal; gave final approval of the version to be published; and agree to be accountable for all aspects of the work. All the authors are eligible to be an author as per the international committee of medical journal editors (ICMJE) requirements/guidelines.

\section{CONFLICTS OF INTEREST}

The authors report no financial or any other conflicts of interest in this work.

\section{ETHICAL APPROVALS}

This study does not involve experiments on animals or human subjects.

\section{PUBLISHER'S NOT}

This journal remains neutral with regard to jurisdictional claims in published institutional affiliation.

\section{LIST OF ABBREVIATIONS}

ELISA: enzyme-linked immunosorbent assay, EDTA: Ethylenediaminetetraacetic acid, MTT: 3-(4,5-imethylthiazol2-yl)-2,5- diphenyltetrazolium bromide, PBS: phosphate buffer saline, $S F$ : subfraction, VCC: vacuum column chromatography.

\section{REFERENCES}

Ahmad I, Ibrahim A. Bioactivity methanol extract and n-hexane fraction of Sungkai leaf Peronema canescens Jack against shrimp larvae Artemia salina Leach. J Sci Heal, 2015; 1(3):114-9.

American Cancer Society. Cancer facts \& figures. 2017. Available via https://www.cancer.org/research/cancer-facts-statistics (Accessed 28 February 2021).

Fadilah F, Andrajati R, Yanuar A, Arsianti A. In-vitro anticancer activity combination of eugenol and simple aromatic benzoate compounds against human colon HCT-116 cells and WiDr cells. J Pharm Sci Res, 2017; 9(5):637-41.
Gautam B. Bioactive natural products chemistry and biology. 1st edition, Wiley-VCH Verlag GmbH \& Co, Weinheim, Germany, 2015.

Geran RI, Greenberg NH, Macdonald MM, Shumacher A, Abbott BJ. Protocols for screening chemical agents and natural products against animal tumors and other biological systems. Cancer Chem Rep, 1972; 3:807.

Halimatushadyah E, Da'i M, Nursid M. Cytotoxicity and apoptosis induction of ethanol extract of sea cucumber Holothuria atra Jaeger, 1833 in some cancer cells. J Postharvest Mar Fish Biotechnol, 2018; 13(2):101-9.

Harmida H, Sarno S, Yuni V. Ethnophytomedicine study in lawang agung village, Mulak ulu district, Lahat regency, South Sumatra. J Penelit Sains, 2011; 14(1):168-287.

Haryati N, Chairul S, Erwin. Toxicity and antibacterial activity test of red leaf extract of red shoots plant (Syzygium myrtifolium Walp.) against Staphylococcus aureus and Escherichia coli bacteria. J Kim Mul, 2015; 13(1):35-40.

Ibrahim A, Kuncoro H. Identification of secondary metabolites and antibacterial activity of Sungkai leaf extract (Peronema canescens Jack.) against several pathogenic bacteria. J Trop Pharm Chem, 2012; 2(1):8-18.

Kitagawa I, Simanjuntak P, Hori K, Nagami N, Taifo M, Shibuya H, Kobayashi M. Indonesian medicinal plants. VII. Seven new clerodanetype diterpenoids, peronemins A2, A3, B1, B2, B3, C1, and D1, from the leaves of Peronema canescens (Verbenaceae). Chem Pharm Bull, 1994; 42(5):1050-5.

Macdonald F, Ford CHJ, Casson AG. Molecular biology of cancer. 2nd edition, BIOS Scientific Publishers, London, UK and New York, NY, 2005.

Mas'ula Y, Kusuma A. Anticancer activity of snake tongue grass plant (Hedyotis difussa Willd.). J Farmaka, 2018; 15(3):17-23.

National Cancer Institute. Physician data query (Pdq). Cervical cancer treatment. 2020. Available via https://www.cancer.gov/types/ cervical/patient/cervical-treatment-pdq (Accessed 27 February 2021).

Panjaitan S, Nuraeni Y. Prospects and techniques for cultivation of Sungkai (Peronema canescens Jack.) in South Kalimantan. J Galam, 2014; 8:25-30.

Rosdiana NA. Antioxidant active fraction from Sungkai bark extract (Peronema canescens Jack.). Bachelor's Theses, Inst Pertan Bogor, 2014; 10-29T: 1-25. Available via http://repository.ipb.ac.id/ handle/123456789/69877. 
Saifudin A. Secondary natural metabolites compound theories, concepts, and purification techniques. 1st edition, Deepublish, Yogyakarta, Indonesia, 2014.

Saleh C, Marliana E. Phytochemical and antibacterial activity test of ethanol extract, n-hexsane, ethil acetat and methanol fractions from the gourds fruit (Lagenari siceraria (Molina) Standl). J Kim Mul, 2011; 8(2):63-9.

Samatha T, Shyamsundarachary R, Srinivas P, Swamy NR Quantification of total phenolic and total flavonoid contents in extracts of Oroxylum indicum L.Kurz. Asian J Pharm Clin Res, 2012; 5(4):177-9.

Sutrisno RB. Thin layer chromatography reagents. 1st edtion, Pancasila University, Jakarta, Indonesia, 1993.

Tropical plants. Peronema canescens Jack. 2019. Available via https://tropical.theferns.info/viewtropical.php?id=Peronema + canescens (Accessed 20 December 2020).

Turner IM. A catalog of the vascular plants of Malaya. Gard Bull Singapore, $1995 ; 47(2): 495$.

Vidyacharani DHA, Arunprasath A. Evaluations of secondary metabolites antioxidant and antimicrobial potential in leaf extracts of Corbichonia decumbens (Forssk.) exell. Asian J Pharm Clin Res, 2020; 13(11):181-3.

Vukovic NL, Obradovic AD, Vukic MD, Jovanovic D, Djurdjevic PM. Cytotoxic, proapoptotic and antioxidative potential of flavonoids isolated from propolis against colon (HCT-116) and breast (MDA-MB-231) cancer cell lines. Food Res Int, 2018; 106:71-80.

Widodo H, Sismindari, Asmara W, Rohman A. Antioxidant activity, total phenolic and flavonoid contents of selected medicinal plants used for liver diseases and its classification with chemometrics, J Appl Pharm Sci, 2019; 9(06):099-105.
Xiong Y, Wu X, Rao L. Tetrastigma hemsleyanum (Sanyeqing) root tuber extracts induces apoptosis in human cervical carcinoma HeLa cells. J Ethnopharmacol, 2015; 165:46-53.

Yang H, Ping DQ. Targeting apoptosis pathway with natural terpenoids: implications for treatment of breast and prostate cancer. Curr Drug Targets, 2010; 11(6):733-44.

Yani AP, Putranto AMH. Examination of the sungkai's young leaf extract (Peronema canescens Jack) as an antipyretic, immunity, antiplasmodial, and teratogenicity in mice (Mus musculus). Int J Sci Eng, 2014; 7(1):30-4

Yao X, Lu B, Lü C, Bai Q, Yan D, Xu H. Taraxerol induces cell apoptosis through a mitochondria-mediated pathway in HeLa cells. Cell J, 2017; 19(3):512-9.

\section{How to cite this article:}

Ibrahim A, Siswandono S, Prajogo EWB. Potential anticancer activities of chloroform subfraction from Peronema leaf on colon cancer HT-29 cells in vitro. J Appl Pharm Sci, 2021; 11(12):082-089. 